\title{
Implementation of Learning Organizations to Achieve Effective Schools in the Efforts to Develop an Elementary School Education Management Model
}

\author{
Riswandi*, Lungit Wicaksono, Mujiyati, Renti Oktaria \\ Department of Education, Faculty of Teacher Training and Education, Universitas Lampung, Indonesia
}

Received April 5, 2020; Revised May 19, 2020; Accepted June 4, 2020

Copyright $(02020$ by authors, all rights reserved. Authors agree that this article remains permanently open access under the terms of the Creative Commons Attribution License 4.0 International License

\begin{abstract}
The purpose of this study is to implement a learning organization to realize an effective school in the framework of developing an elementary school management model. The implementation is carried out by applying five components, namely personal mastery, system thinking, mental models, shared vision and team learning. This research uses a quantitative approach with a quasi-experimental design. The sampling technique used is purposive sampling. Research data collection was carried out using an effective school measurement instrument consisting of 40 assessment indicators. The instruments were analyzed using the Rasch Model approach through the Winstep program. Data analysis techniques used t-test. The results showed that the learning organization in the education management model can improve effective schools in the aspects of input, process, output, and feedback. Data analysis was performed using the Rasch Model approach through the Winsteps program for Effective School scale measurement instruments. Alpha Cronbach's value of 0.75 which measures reliability is the interaction between person and items as a whole that are in the good category. The unidimensionality of instruments is an important measure to evaluate whether the instrument is capable of measuring what it should be. Raw variance data is $26.1 \%$. This shows that a minimum requirement of $20 \%$ can be fulfilled. From the calculation, results show that $\mathrm{t}$-count $\geq \mathrm{t}$-table, which is $5.975 \geq 1.664$. It can be stated that the learning organization in the effective education management model can improve effective schools in primary schools in Pringsewu District.
\end{abstract}

Keywords Learning Organization, Effective School, School Education Management

\section{Introduction}

Schools are formal educational institutions, which are expected to provide the basic knowledge, skills, and attitudes needed to shape and develop a whole person. The implementation of education must guarantee equality and improve the quality of education to create intelligent, productive and highly competitive human beings. Improving the quality of education is one of the important discourses in the administration of the national education system, so efforts are needed to improve the quality of education in Indonesia at every level and education unit.

The effort to improve the quality of education begins with the good quality of school education management at all levels of education. The process in school education management is the main activity needed as a driver of organizational quality success. Management education is a study and practice that are directed in the organization's operations (Bush \& Coleman, 2000). Carrying out educational organizations needs a form of activity regulation that leads to systematic conditions as a benchmark in the implementation of operational activities.

Education management is an activity or a series of activities in the form of a collaborative process of managing a group of people who are members of an educational organization, to achieve predetermined goals, to be effective and efficient (Arikunto \& Yuliana, 2008). In management, collaboration, a group of people, and goals to be achieved are needed. Activities managed to include several things; (1) student affairs; (2) personnel; (3) curriculum; (4) facilities; (5) financing: (6) related educational institutions; (7) community relations (Arikunto \& Yuliana, 2008).

The organization has an important influence on the environment because it is a system in which it interacts with its environment. Organizations must be adaptive to the development of complex environments, and responsive in the face of world competition that continues to develop. 
Organizational ability is needed in changing knowledge with the learning process. To achieve these goals, it is necessary to have managerial skills possessed by the principal in developing a model of school education management.

One of the things that have considerable influence on the success of an organization is the leader of the organization itself. The leader is the party that directs, makes policies and often indirectly creates a culture in an organization. Therefore, high commitment is needed in building and developing strategic resources.

A learning organization is a concept in a dynamic organizational environment and is a strategy for achieving success. Learning in organizations is a shared process, where people will learn continuously in expanding their capacity to create the results they want, where people can find new patterns and broad thinking and collect common aspirations and where people are constantly learned how to study together (Senge, 1990). Organizational learning has clear general insights at all levels of the organization and the highest leaders who are responsible for ensuring the circumstances and development (Purhaghshenas \& Esmatnia, 2012). Effective learning is a learning process that comes from one's desires, not because of coercion from related companies/institutions (Any, 2009).

Leadership is something a leader has to influence the attitudes and motivations of individual followers (Yukl, 2010). Criteria of the success of an organization can be seen from several things, namely; (1) The achievement of organizational goals, (2) The organization can meet and utilize all available resources to the maximum, (3) Subordinates and business partners are satisfied, (4) There is an agreement between members in the organization and various levels of what is being and will be done; (5) The organization provides services to the best interests of the community (Wahab, 2008).

The concept of a learning organization needs to be continuously implemented to improve and develop organizational performance despite environmental changes. Schein (1992) argues that to be able to survive in a very dynamic environment, organizations must maintain an internal culture that supports learning from experience.

The purpose of this research is to implement a learning organization to achieve effective schools in developing the management of elementary school education in the Pringsewu District. The results obtained are expected to be able to contribute to ways, tips and interventions to optimize learning organizations in achieving effective schools in primary school education.

\section{Literature Review}

Learning organization is a skill and process for creating, obtaining, and transforming knowledge, as well as the distribution, translation, and delivery of information by new knowledge and ideas that can be accessed by all organizations and are relevant to the core objectives (Schermerhorn, Hunt, \& Osborn, 2003). The success or success of an institution can be seen from the changes and organizational performance through learning (Rose, Kumar, \& Pak, 2009). A good learning organization is an organization that can respond positively to changes, interactions, continuity, development, and complex situations.

Organizational learning is defined as changes in the organization's knowledge base that occur due to experience. Learning organization has been described as an outcome or product of organizational learning, which is complex and multidimensional in its approach. Organizational learning, can be in the form of knowledge creation, knowledge retention, and transfer of knowledge (Odor, 2018). Changes in organizations can be progressive, leading to significant, and regressive changes that arise from the organizational learning process. Organizational dynamics arise from organizational learning proposals and interactions between power relations and individual and collective emotions (Flood \& Romm, 2008).

This organization is skilled at creating, obtaining and transfering knowledge, and modifying their behavior to reflect knowledge and insight (Odor, 2018). Organizational learning always faces challenges regarding empirical results due to lack of research on the definition of certain concepts and guidelines on how to apply them. The aim of learning organizations is to increase individual and collective awareness, which results in changes in themselves (Rupčic, 2018).

Here are three basic things that can facilitate a person in understanding the concept of a learning organization, namely the learning process of the organization, collective thinking related to a group of people and competencies, and a systematic environment in which every component of the organization can be connected to enable continuous learning. Learning organizations are seen as an integrative system that is implemented in the workplace and environment to support the learning process (Watkins \& Marsick, 1997).

Integrative systems intended in learning organizations are learning, organization, people, knowledge, and technology. The five parts of the learning organization system need to actively support each other so that they can develop continuously and achieve further organizational success (Marquardt, 2002). To improve and expand the field of learning, four parts of the learning organization system model are needed, namely people, technology, knowledge, and organization.

Aspects of learning skills in maximizing learning organization can be achieved by referring to five key skills, namely systemic thinking (systems thinking), mental models, personal mastery, self-directed learning, and dialogue. While Senge (1995) proposes five learning skills to build learning organizations, namely systemic thinking, personal mastery, mental models, building shared vision, 
and team learning.

The level of learning that is one of the main processes in a learning organization can influence teacher behavior, school culture, and school performance. There are three levels of learning, namely individual learning, group learning, and organizational learning (Marquardt, 2002). While learning is carried out using three types of significant approaches, including adaptive learning, anticipatory learning, and action learning. Although these three types of learning are different, the three complement each other.

There are components such as school principals, teachers, staff, students, and communities, who have different tasks in an organization called a school. According to Preedy (1993), what is included in the category of effective schools is the situation of schools that get support from the environment and are led by capable leaders in management and making decisions, by involving their staff. In line with this, Scheerens \& Scheerens (1992) stated that effective schools were schools that have high efficiency and productivity and have strong organizations to produce quality graduates.

If in the beginning, the effectiveness of the school was seen in terms of the completeness of the facilities and infrastructure, the current school effectiveness should be more determined by how the school management was carried out. According to Riswandi (2016) to measure the effectiveness of a school can be determined and observed from three levels, namely schools, classes, and students. This indicates that an effective school is a school that can empower every important component of the school, both internal and external and has a good, transparent and accountable school management system.

School effectiveness is a very broad concept that accepts different definitions from different perceptions. Following the existing literature, the majority of past researchers about school effectiveness defines the concept from the standpoint of academic achievement as an index to be used in assessing effective schools where all students are educated regardless of their socio-economic and family affiliations (Pihie, Dahiru, \& Ramli Basri, 2018). The ideas that underlie effective school theory are about significant factors in schools, such as student achievement and well-being, and also about negative relationships such as bullying behavior. Good leaders in schools make clear guidelines in accordance with effective school principles, with the hope of having a positive impact on students (Ramberg, Brolin Låftman, Fransson \& Modin, 2019).

Furthermore, Scheerens \& Scheerens (1992) mentions, "since school effectiveness is a casual concept, not only the type of effect but also the dimensions of the cause or means that should be considered." The school decides for the need to change and improve the school, then prepares a development plan for further implementation in such a way as to create a situation for the school to improve continuously.

Hoy \& Miskel (2005) states that things that can make schools an effective school are educational leadership, planned curriculum, clear goals, awareness of academic success, orderly atmosphere, community awareness, support and involvement of parents, school management both in the development and balance of staff work, joint planning, and direct support for schools. Whereas Lezzotte \& Mckee (2002) states that there are five things related to effective schools, namely setting new missions, developing systems, using high-yield strategies, creating partnerships, and guidance from leaders.

School management empowers human resources available in schools and facilities and infrastructure efficiently. This can be used as an alternative to creating an independent school and has a high advantage. Through school management, school authority and management rest on schools and directly related stakeholders. On this basis, school management functions are more open and optimal, avoiding centralized and bureaucratic formats that can cause the loss of school management functions.

School management is based on the fact that every school, like every individual, has its uniqueness. Each school has different local characteristics, contexts, and conditions that no other school has. To optimize the education process in each school, the school needs to manage the school according to that context. To optimize the management of education in a school, unique management is needed that is adjusted to the conditions of the school, as well as students. This is by the management function, as expressed by Stoner (2006) that there are five management functions, namely planning, organizing, staffing, directing, and controlling.

\section{Methods}

\subsection{Research Design}

This research uses a quantitative approach in which data processing is performed by statistical methods. This research method was conducted to obtain the significance of group differences or relationships between the variables studied. In the context of this study, the quantitative method is intended to find out the difference between before and after treatment. The type of research design used is quasi-experiment, which is a design that allows researchers to control as many variables as possible from the situation (Creswell, 2010). This Design does not control variables as fully as in actual experiments, but researchers can calculate any variables that are impossible to control, which sources of error may be present in interpreting the results of research. The quasi-experimental design used was "pretest-posttest one group design" (Muri Yusuf, 2005). This design is an experimental design conducted with a pre-test before the 
treatment is given, and post-test after the treatment is given.

\subsection{Data Collection}

Research data collection using effective school measurement instruments. This instrument is composed of 40 assessment indicators that refer to the School as a system that has inputs, processes, outputs, and feedback (Widodo \& Kadarwati, 2013). The instruments were analyzed using the Rasch Model approach through the Winsteps program. In the Rasch Model approach, analysis is done by paying attention to items, aspects of the respondent and calculating the magnitude of the correlation. According to Sumintono \& Widhiarso (2014), the superiority of Rasch Model compared to classical test theory, namely the ability to predict missing data, based on individual response patterns.

\subsection{Subject of Study}

The study population was all elementary school teachers in Pringsewu District. The sampling technique in this study used purposive sampling. The determination of this sample is adjusted to the existence of the problem and the type of data that you want to collect. In this study, the sample of this research was 78 people.

\subsection{Data Analysis Technique}

The results of the research data are tested for normality and homogeneity of the data. If it meets the criteria, then the data is tested for effectiveness using an independent t-test. The technique is intended to assess the effectiveness of a treatment in changing a behavior by comparing the situation before the situation after the treatment was given.

\section{Results}

\subsection{Test Reliability and Estimation Validity through Principal Component Analysis}

The analysis was carried out in three stages, namely considering the reliability of each item, the reliability of each sample, and the reliability of interactions between the sample and items on an effective school measurement instrument.

Table 1. Test Reliability Winsteps Program

\begin{tabular}{cc}
\hline Estimation & Measure \\
\hline Items reliability & 0,94 \\
\hline Person reliability & 0,71 \\
\hline $\begin{array}{c}\text { Cronbach alpha (KR-20) person raw score } \\
\text { "test" reliability }\end{array}$ & 0,75 \\
\hline
\end{tabular}

Data were analyzed using the Rasch Model approach through the Winsteps program for Effective School scale measurement instruments. Data input consists of 78 people with 40 items. Alpha Cronbach's value of 0.75 which measures reliability is the interaction between person and items as a whole that are in the good category. A person's reliability value of 0.71 shows that the consistency of respondents' answers in the good category and item reliability of 0.94 indicates that the quality of the items in the category is very good.

Unidirectionally is a measure to be able to see that an effective school measurement instrument can measure what should be measured. This modeling was developed based on principal component analysis.

Table 2. Standardized Residual Variance in Winsteps Program

\begin{tabular}{|c|c|c|c|c|}
\hline \multirow[b]{2}{*}{$\begin{array}{c}\text { Total raw variance in } \\
\text { observations }\end{array}$} & \multicolumn{2}{|c|}{ Empirical } & \multicolumn{2}{|c|}{ Modeled } \\
\hline & 54.1 & $100.0 \%$ & & $100.0 \%$ \\
\hline $\begin{array}{c}\text { Raw variance } \\
\text { explained by measures }\end{array}$ & 14.1 & $26.1 \%$ & & $26.1 \%$ \\
\hline $\begin{array}{c}\text { Raw variance } \\
\text { explained by persons }\end{array}$ & 1.7 & $3.1 \%$ & & $3.1 \%$ \\
\hline $\begin{array}{c}\text { Raw Variance } \\
\text { explained by items }\end{array}$ & 12.5 & $23.0 \%$ & & $23.0 \%$ \\
\hline $\begin{array}{l}\text { Raw unexplained } \\
\text { variance (total) }\end{array}$ & 40.0 & $73.9 \%$ & $100.0 \%$ & $73.9 \%$ \\
\hline
\end{tabular}

The unidimensionality of instruments is an important measure to evaluate whether the instrument is capable of measuring what it should be. Raw variance data is $26.1 \%$. This shows that a minimum requirement of $20 \%$ can be fulfilled.

\subsection{Test for Normality and Homogeneity of Data}

Table 3. Normality of Data Before Treatment

\begin{tabular}{lccc}
\hline & \multicolumn{3}{c}{ Kolmogorov-Smirnova } \\
\cline { 2 - 4 } & Statistic & df & Sig. \\
\hline Results_Before_Treatments & .116 & 78 & .011
\end{tabular}

From the results of these data stating that the value of p-value (sig.) $<0.05$ with a significant value of $0.011<$ 0.005 , it is concluded that the data taken from the population in the data before the treatment is normally distributed.

Table 4. Normality of Data After Treatment

\begin{tabular}{cccc}
\hline & \multicolumn{3}{c}{ Kolmogorov-Smirnov $^{\mathrm{a}}$} \\
\cline { 2 - 4 } & Statistic & df & Sig. \\
\hline $\begin{array}{c}\text { Results_after } \\
\text { Treatment }\end{array}$ & .099 & 78 & .057 \\
\hline
\end{tabular}

Based on the results of the table data which states that the value of p-value (sig.) $<0.05$ with a significant value of $0.057<0.005$, it is concluded that the data taken from the population in the data after treatment are also normally distributed. 
Table 5. Test of Homogeneity of Variance

\begin{tabular}{ccccccc}
\hline & & Levene Statistic & df1 & df2 & Sig. \\
\hline \multirow{3}{*}{ Score } & Based on Mean & .252 & 1 & 154 & .617 \\
\cline { 2 - 6 } & Based on Median & .248 & 1 & 154 & .619 \\
\cline { 2 - 6 } & Based on Median and with adjusted df & .248 & 1 & 147.2 & .619 \\
\cline { 2 - 7 } & Based on trimmed mean & .235 & 1 & 154 & .628 \\
\hline
\end{tabular}

Based on the above data it is known that the value of sig.leven's test for equality of variance for the experimental group is 0.617 where the value of p-value (sig.) $<0.05$ with a significant value of $0.617<0.005$, it is concluded that the variance in each data group is homogeneous.

\subsection{Results of Data Analysis}

Learning organization testing to improve effective schools are done by using the t-test technique. The results of data processing are presented in the following Table 6.

Table 6. Test Group Differences

\begin{tabular}{ccccccc}
\hline Class & Mean & Std. Deviation & t- count & t-table & Sig. (2-tailed) & Description \\
\hline Before & 142,06 & 13.533 & 5,975 & 1,664 & 0,000 & Significant \\
After & 152,78 & 15.614 & & & & \\
\hline
\end{tabular}

Table 6 shows the t-count of 5.975 with the level of a sign. (2-tailed) $=0,000$ with $\mathrm{df}=77$, so the t-table value $=$ 1,664 at the significance level $(\alpha=0.05)$. From the calculation, results show that $\mathrm{t}$-count $\geqslant \mathrm{t}$-table, which is $5.975 \geqslant 1.664$. It can be stated that the learning organization in the effective education management model can improve effective schools in primary schools in Pringsewu District.

\section{Discussion}

The results showed that the learning organization in the education management model can improve effective schools both in the aspects of input, process, output, and feedback aspects. This is because the learning organization in education management, which is implemented as a process of improving the quality of education in primary schools, is applied efficiently.

A good education system from an early age will determine the success of education at a higher level. Factors such as the teacher, the number of students in each class, the completeness of the curriculum of the book, the facilities, the infrastructure used and the operational management of education used to determine the quality of basic education. Educational management implies a systematic and comprehensive collaborative process to realize national education goals (Mulyasa, 2007).

Management education is defined as everything related to the management system to achieve stated goals. The quality of education in an institution will affect the effectiveness and efficiency in its application. the management level is marked by clarity in the planning, organizing, implementing and monitoring functions. If these functions run well, the implementation of education can run smoothly. Schools that develop good education management will be able to achieve effective schools. This is confirmed by the results of research conducted by Riswandi (2016) which states that one of the efforts to create this in primary schools is to implement comprehensive school management and development plans for school work programs.

Primary school management is a process in which the principal as the administration seeks to achieve the institutional goals of the school efficiently. Primary school management is a process of activities that the principal seeks for the interests of the school.

This series of activities is carried out by the principal along with other components, and utilizes all available facilities, so the principal does not work alone. The principal always tries to assign other people to complete tasks in their school. Elementary school management is all the process of utilizing all components, both human and non-human components owned by the school to achieve goals efficiently. Primary school management aims to achieve the institutional goals of elementary schools, namely to provide students with basic abilities to develop their lives as individuals and community members and to prepare students for secondary education.

Learning organization is used as a reference in this study because these components are considered more appropriate in forming effective schools. The first aspect is that systemic thinking is a comprehensive way of thinking to understand complex circumstances by analyzing the parts of the system and connecting the elements making up the system so that a good relationship 
pattern is formed.

About forming effective schools, learning organizations view schools as a system consisting of various interrelated components. These components include the curriculum, infrastructure, students, public relations, libraries, and laboratories (Adi, 2000). Each component is interrelated with one another so schools need to develop these components together. Systemic thinking skills can help stakeholders in schools to see how to change existing systems so that the learning process and organizational actions can be done more effectively, systematically, and holistically.

We explore learning organizations as a system, involving individuals, teams and organizations (Bui \& Baruch, 2010). Analysis shows that age and years of teaching experience are related to teachers' perceptions of their school as a learning organization. In particular, older and more experienced teachers agreed that their school operates as a learning organization. This is consistent with educational research, which shows that teacher experience factors are related to their job satisfaction (Armaou, \& Antoniou, 2018).

Personal mastery is a learning skill to improve the quality of stakeholders to achieve the desired results and create an organizational environment on target. The basic components to build a learning organization, among others, can clarify and deepen the energy vision of self-focus, develop patience, see reality and objectively.

Mental models are skills or thinking patterns that are reflected in attitudes, behavior, and actions. These thinking skills are continuously carried out through contemplation, clarification, and understanding of the world based on assumptions, experiences, principles, and values that are loaded with morals and ethics. Mental models affect a person's ability to understand the problems they face. Mental models can give an idea of how someone thinks so that they can explain why and how someone determines a decision or an action (Tarigan, 2016; Senge, 1995).

Building a shared vision illustrates the ability of an organization informing the commitment of its members. A shared vision is carried out by taking a picture of the future of the organization that was created together and establishing the principles of long-term activities as a guideline for its members (Sange, 1995). Meanwhile, team learning is the ability and willingness of organizational members to work as a team and think collectively and synergistically. In applying it, the role of parents is needed because the perception of parents will affect the perception of children, especially in elementary school children (Adiputra, Mujiyati, \& Hendorwati, 2019).

\section{Conclusions}

The concept of learning organization needs to be continuously implemented to improve and develop performance despite environmental changes. This study attempts to implement a learning organization to achieve effective schools in developing management of primary school education in Pringsewu District. From the results of this study what is concluded is that the Learning organization in the model of effective education management can improve effective schools in general in the aspects of input, process, output, and feedback. Future studies are expected to be able to try to apply this method in different educational settings and larger subjects. The results obtained are expected to contribute to ways, tips and interventions to optimize learning organizations in achieving effective schools in primary school education.

\section{Acknowledgements}

The authors would like to thank the University of Lampung for funding this research.

\section{REFERENCES}

[1] Adi, W. (2000). Strategi pembelajaran. Yogyakarta: FIP UNY.

[2] Adiputra, S., Mujiyati, \& Hendorwati, T.Y. (2019). Perceptions of Inclusion Education by Parents of Elementary School-Aged Children in Lampung, Indonesia. International Journal of Instruction, 12(1), 199-212.

[3] Any, Noor. (2009). Management Event. Bandung: Alfabeta.

[4] Arikunto, S., \& Yuliana, L. (2008). Manajemen pendidikan. Yogyakarta: Aditya Media.

[5] Armaou, M., \& Antoniou, A. S. (2018). Secondary School Teachers' Perceptions of Job Resources in Learning Organizations. Multilingual Academic Journal of Education and Social Sciences, 6(1), 4-20.

[6] Bui, H. \& Baruch, Y. (2010), "Creating learning organizations: a systems perspective", The Learning Organization, Vol. 17 No. 3, pp. 208-227.

[7] Bush \& Coleman. (2000). Leadership and Strategic Management in Education. Houston: SAGE.

[8] Creswell, John W. (2010). Research Design, Pendekatan Kualitatif, Kuantitatif dan Mixed. Penerjemah. Ahmad fawaid. Yogyakarta: Pustaka Pelajar.

[9] Hoy, W., \& Miskel, C. (2005). Education administration: Theroy, research, and practice (7th ed.). New York: McGraw-Hill.

[10] Lezotte, L. W., \& Mckee, K. M. (2002). Assembly required: A continuous school improvement system. Effective Schools Products.

[11] Marquardt, M. J. (2002). Building the learning organization: Mastering the 5 elements for corporate learning. Palo Alto, 
CA: Davies.

[12] Mulyasa, E. (2007). Menjadi Guru Profesional menciptakan Pembelajaran Kreatif dan Menyenangkan. Bandung: Rosdakarya.

[13] Muri Yusuf, A. (2005). Metodologi Penelitian, Dasar-dasar Penyelidikan Ilmiah. Padang: UNP Press.

[14] Odor, H. O. (2018). A literature review on organizational learning and learning organizations. International Journal of Economics \& Management Sciences, 7(1), 1-6.

[15] Pihie, Z. A. L., Dahiru, A. S., \& Ramli Basri, S. A. (2018). Relationship between Entrepreneurial Leadership and School Effectiveness among Secondary Schools. International Journal of Academic Research in Business and Social Sciences, 8(12).

[16] Preedy, M. (Ed.). (1993). Managing the effective school. SAGE.

[17] Purhaghshenas, S. H., \& Esmatnia, M. (2012). Learning organizations. Interdisciplinary Journal of Comtemporary Research in Business, 4(7), 243-249.

[18] Ramberg, J., Brolin Låftman, S., Fransson, E., \& Modin, B. (2019). School effectiveness and truancy: a multilevel study of upper secondary schools in Stockholm. International Journal of Adolescence and Youth, 24(2), 185-198.

[19] Riswandi, R. (2016). Pelatihan manajemen sekolah sebagai upaya untuk menciptakan sekolah efektif pada sekolah dasar di Kabupaten Tanggamus. Jurnal Tarbiyah, 22(1).

[20] Robert L. Flood, Norma R.A. Romm, (2018) "A systemic approach to processes of power in learning organizations: Part I - literature, theory, and methodology of triple loop learning", The Learning Organization, Vol. 25 Issue: 4, pp.260-272,

[21] Rose, R. C., Kumar, N., \& Pak, O. G. (2009). The effect of organizational learning on organizational commitment, job satisfaction and work performance. Journal of Applied Business Research (JABR), 25(6).

[22] Rupčić, N. (2018), "Complexities of learning organizations - addressing key methodological and content issues", The Learning Organization, Vol. 25 No. 6, pp. 443-454.

[23] Scheerens, J., \& Scheerens, J. (1992). Effective schooling: Research, theory and practice. London: Cassell.

[24] Schein, E. H. (1992). How can organizations learn faster?: the problem of entering the Green Room.

[25] Schermerhorn Jr., John R., James G. Hunt, \& Richard N. Osborn. (2003). Organizational Behavior, Eighth Edition. New York: John Wiley.

[26] Senge, P. (1995). On schools as learning organizations: A conversation with Peter Senge. Educational Leadership, 52(7), 20-23.

[27] Senge, Peter M. (1990). The Fifth Discipline. The Art and Practice of The Learning Organization. New York: Doubleday Currency.

[28] Stoner, James A.F. (2006). Manajemen, Terjemahan: Antarikso. Jakarta: Erlangga.

[29] Sumintono, B., \& Widhiarso, W. (2014). Aplikasi model rasch untuk penelitian ilmu-ilmu sosial. Jakarta: Tim Komunikata Publishing House.

[30] Tarigan. (2016). Menulis Sebagai Suatu Keterampilan Berbahasa. Bandung: CV Angkasa.

[31] Wahab, Solichin. (2008). Analisis Kebijakan: Dari Formulasi ke Implementasi Kebijakan Negara Edisi Kedua. Jakarta: Bumi Aksara.

[32] Watkins, K. E., \& Marsick, V. J. (1997). Dimensions of the learning organization questionnaire. Warwick, RI: Partners for the Learning Organization.

[33] Widodo, T., \& Kadarwati, S. (2013). Higher order thinking berbasis pemecahan masalah untuk meningkatkan hasil belajar berorientasi pembentukan karakter siswa. Jurnal Cakrawala Pendidikan, 5(1).

[34] Yukl, G. (2010). Leadership in Organization. Seventeenth Edition. New Jersey: Person. 